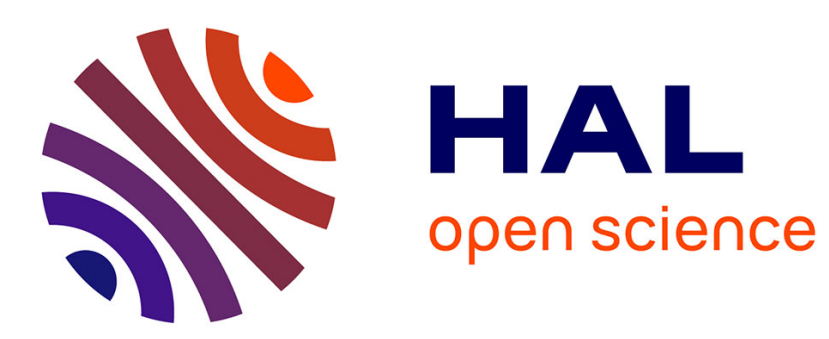

\title{
The productivity Challenge in Services: Measurement and Strategic Perspectives
}

\author{
Faridah Djellal, Faïz Gallouj
}

\section{To cite this version:}

Faridah Djellal, Faïz Gallouj. The productivity Challenge in Services: Measurement and Strategic Perspectives. Service Industries Journal, 2013, 33 (3-4), pp.1-18. halshs-01133198

\section{HAL Id: halshs-01133198 \\ https://shs.hal.science/halshs-01133198}

Submitted on 18 Mar 2015

HAL is a multi-disciplinary open access archive for the deposit and dissemination of scientific research documents, whether they are published or not. The documents may come from teaching and research institutions in France or abroad, or from public or private research centers.
L'archive ouverte pluridisciplinaire HAL, est destinée au dépôt et à la diffusion de documents scientifiques de niveau recherche, publiés ou non, émanant des établissements d'enseignement et de recherche français ou étrangers, des laboratoires publics ou privés. 
Published in the Service Industries Journal: DJELLAL F., GALLOUJ F. (2013), The productivity challenge in services: measurement and strategic perspective, The Service Industries Journal, Vol. 33, n³-4, February, p. 1-18.

\author{
The productivity Challenge in Services: Measurement and Strategic Perspectives \\ Faridah Djellal and Faïz Gallouj \\ Clersé University Lille 1
}

\begin{abstract}
:
The concept of productivity is at the heart of economic theory, management science and operational management of firms and organizations. Despite the theoretical and operational importance of this concept, in recent years, its absolutism has been challenged. Services are often at the heart of this critical debate. Both conceptually and methodologically, services are indeed a major challenge to the concept of productivity. The objective of this paper is to review issues raised by services and their relationships with productivity, from two different but related perspectives: 1) a theoretical and methodological perspective focused on the problems involved in defining and measuring productivity, and 2) a strategic perspective focused on identifying generic productivity and performance strategies in service firms and organizations.
\end{abstract}

Key words: services, productivity, performance

\title{
Introduction
}

The concept of productivity is at the heart of economic theory (orthodox or heterodox), management science and operational management of firms and other organizations. For a firm, organization or nation, productivity is measured in terms of productive efficiency, that is to say, the relationship between the production of goods and services and the factors of production mobilized. Productive efficiency is clearly related to a number of key economic variables, including growth and living standards, the competitiveness of an economy and the employment level.

Despite the theoretical and operational importance of this concept, in recent years, a debate has been sparked that seeks to challenge not so much the concept itself, but rather its scope considered as universal by economists (Schwartz, 1992; Gadrey, 1996, 2002; Bonneville, 2001; Sturm et al., 2011). Supporters of this debate denounce what Gadrey calls the "absolutism" of productivity (and the related concept of growth) and argue for a pluralistic approach to performance.

The need to move beyond the absolute power of productivity (and growth) is justified by a number of arguments, which we will briefly review (Gadrey, 1996; Djellal \& Gallouj, 2008):

1) Despite steady progress, productivity is still poorly measured (difficulty to gather data, to integrate quality and innovation, particularly unsatisfactory indicators especially in public services and more generally in non-market services).

2) In some situations, the validity of the concept itself is in question. There are numerous examples of this, but the best one is the case study suggested by Baumol (1967): how to 
increase the productivity of a wind quintet? Certainly not by increasing the playing speed of the musicians.

3) In other situations, other key performance issues (considered in terms of outcome) reduce the importance of the concept of productivity and make it secondary. For example, for a hospital facing a serious epidemic, productivity is not the priority.

4) Growth and productivity can be the source of negative externalities, which can affect health, the environment, quality, fairness, etc.

5) More generally, it is increasingly recognized that the level of production of goods and services is not the only or best indicator of the well-being of a society. Alternatives to the GDP, like Osberg and Sharpe's index of economic well-being (Osberg \& Sharp, 1998) and ISEW (Index of Sustainable Economic Welfare) have been suggested. This search for alternative indicators of wealth has been revived through the work of the Stiglitz-Sen commission (Stiglitz, Sen \& Fitoussi, 2009).

Services are often at the heart of this critical debate. Services are indeed a major challenge to the concept of productivity (Ganz \& Mörschel, 2011; Kicherer et al., 2011; Linna et al., 2010). It should be remembered that it was the low rate of productivity growth that was the first positive (that is to say non-residual) definition of services (Clark, 1940; Fourastié, 1949). This hypothesis of an intrinsic and natural weakness of productivity of services is challenged by contemporary debates suggesting that productivity in services is often poorly measured and sometimes even conceptually inappropriate. The objective of this paper is to review issues raised by services and their relationships with productivity, from two different but related perspectives: 1) a theoretical and methodological perspective focused on the problems involved in defining and measuring productivity, and 2) a strategic perspective focused on identifying generic productivity strategies.

This article is organized into three sections. The first section is devoted to analytical problems involved in defining and measuring productivity in market and non-market (especially public) services. In the second section, we review the main measurement methods used and discuss alternative approaches based on the plurality of value and judgment systems. In the final section, we examine, in very general terms the productivity strategies implemented in service firms and other organizations and how they relate to the different concepts of productivity and performance.

\section{The Specific Characteristics of Services and their Impact on Productivity}

The concept of productivity is actually a Fordist industrial concept and poses few (or fewer) problems when dealing with standardized products (goods or services). It is quite different in an intangible, knowledge and service economy. To address these difficulties, we will implement what was called in another context, it is true, (service "innovation studies") a demarcation or differentiation perspective (Gallouj, 1994; Gallouj \& Weinstein, 1997; Combes \& Miles, 2000) as opposed to an assimilation perspective. The assimilation perspective regards (standardized) services as if they were material goods, and it measures productivity in services by simply applying the traditional industrial methods. The demarcation perspective focuses on the specific characteristics of services and examines their impact on the issue of productivity.

The intrinsic technical characteristics differentiating goods from services have been extensively covered in economics and management literature for several decades (Hill, 1977; Gadrey, 2000). Some of them are common to all services, whether market or non-market (in 
particular public). Others are specific to public services. In the following paragraphs we discuss the impact of these characteristics (distinguishing between general characteristics and those specific to public services) on the definition and indicators of productivity (see Table 1).

\subsection{The Specific Characteristics of Services and their Impact}

The approach of examining the intrinsic characteristics of services is interesting, especially because it provides simple criteria for describing activities and deductively addresses the impact of the characteristics on the economic variable in question (productivity and performance in this case, but it could be innovation, exchange, etc.). The technical characteristics of services most often discussed in the literature are intangibility and interactivity. But there are two others that are of fundamental importance as regards the issue of productivity: the time factor and the social nature of the product, i.e. the time and social embeddedness of the product.

\section{a) Intangibility}

Adam Smith (1960) is generally credited with authorship of the idea of the intangibility of services. Focusing mainly on public servants, domestic servants, artists, lawyers and doctors, Smith wrote in The Wealth of Nations "services perish in the very instant of their production..." This supposedly intrinsic technical characteristic of services was (and still is) at the heart of contemporary research on services, whether in economics or management. This means that unlike a good, which is inseparable from the technical components that allow its existence, a service is unsubstantial, evanescent and perishable. It does not have a "tangible" form that can be accumulated and circulate economically independent of its support (a good, an individual). It is not a given entity; it is a process, an act, a change of state. One cannot "sell" or "transfer" such a state. Nor can it be "repaired," at least in terms of repairing a tangible good.

Intangibility has many implications when it comes to defining and measuring productivity. 1) In the case of material goods, identifying the product or unit of output, that is to say the expression of the numerator in the productivity ratio, is generally easy (for example, the unit of output of an automobile manufacturer is an automobile). However, determining the unit of output of an intangible service is more difficult. Some authors (Delaunay \& Gadrey, 1987) have even used the expression "desperate search" for outputs. What is the unit of output of a consulting firm, a bank or a hospital? This does not mean that there is no answer to this question, but rather that there are multiple, contradictory answers, each just as legitimate as the others.

2) It is also difficult to distinguish the product from the factors of production that contribute to its realization (i.e., the product from the process). This has led some theoretical models (e.g., Baumol, 1967), but above all the national accounts, to define (especially in public services) the product by the factors of production, in other words, the output by the input.

3) Finally, it is equally difficult to define innovation and quality improvement, which is problematic for a relevant measure of productivity.

\section{b) Interactivity}

Interactivity means that the customer participates in the production of the service: he or she co-produces the service. This idea of co-production has often been placed at the heart of the definition of services. Some authors even suggest including the customer as an input in the production function (Oï, 1992; Martin et al., 2001). Indeed, especially with IT and networks, in which the consumer uses not only his own labor, but also his own technologies (computers, 
Internet) to co-produce the service, one could also include the amount of capital provided by the customer.

The participation of the customer in the process of producing the service has numerous consequences.

1) It makes it difficult in some cases, to define and identify the "product." Indeed, the product is always different, tailored to specific needs. This is particularly true in knowledge-intensive services (such as consulting). In this particular case, some consultants claim that many of their transactions are innovations (which is questionable in our opinion), insofar as they always involve new problems in different contexts for different clients.

2) It also makes it difficult to assign the labor input and the capital input to the unit of output when measuring productivity. This is particularly true of service relationships with consultants, subcontractors, etc. which are the source of indirect productivity for their clients, but it is also true of self-service or on-line service relations that mobilize not only the customer's work, but also his own technologies for co-producing the service.

3 ) The productivity of the service provider can be strongly influenced by the quality of the customer (consumer or user) involved in the service production process. This is particularly evident in the case of education where good students have a positive influence on the performance of the teacher or the school. It is also true for consulting services where the phrase "you get the consultant you deserve" expresses the correlation between the level of quality of the client and the level of performance of the consultant. A competent client is able to increase the performance of the consultants he or she uses.

\section{c) Time factor}

The time factor of services means that their output should not be considered only statically but also dynamically. It exerts its effects over time and it is therefore necessary to distinguish the short-term service (the output) from its medium and long term effects (the outcome). In the case of hospital services, the output means the patient care, while the outcome is the change in the patient's health status, his or her subsequent state of health (a longer life due to the care received).

This distinction between output and outcome is important because it helps identify several possible definitions of performance:

1) productivity (or productive efficiency) in the true sense, which is the ratio between outputs and inputs $(\mathrm{Q} / \mathrm{F})$,

2) economic efficiency (or cost efficiency), which reflects the ratio between outputs and costs $(\mathrm{Q} / \mathrm{C})$,

3) effectiveness meaning the longer term result of the use of inputs (the ratio between outcome and inputs $\mathrm{R} / \mathrm{F}$ ),

4) economic effectiveness, that is to say the ratio between the outcome and costs (R/C).

These concepts of performance are sometimes used (incorrectly) as synonyms. This is the case, for example, of a strategy defined as labor productivity improvement, which is focused on "cost-cutting." But these concepts can also compete with one another. For example, particularly in public services, some actors may believe that outcome-based performance measurements are more legitimate than output-based performance measurements.

\section{c) Social nature}

In general, it can be said that unlike goods, a service is not an objective entity embodied in its technical specifications. Its definition is quite subjective. It depends on the value system or 
judgment criteria that are valued, i.e. on the output "convention" that is adopted. The service is thus a social construction. This is especially true for public services where, as we will see, certain principles are important (equality, fairness, continuity), but it is also true for market services.

The social nature or social embeddedness of the service suggests that complementary and competing concepts of product and performance may exist. These vary depending on the evaluation criteria favoured, the value system, the reference world that the evaluator is part of (civic, technical, market, social worlds). For example, in the case of health services, the medical staff (and patients) may focus on the quality of care, while the health authorities are also particularly sensitive to saving resources. The social nature of the service and its consequences are at the heart of the multi-criteria methods for evaluating performance that we will discuss in section three.

Table 1: The characteristics of market and public services and their impact on productivity

\begin{tabular}{|c|l|}
\hline Characteristics & Impacts on productivity \\
\hline General characteristics of services & \\
\hline Intangibility & $\begin{array}{l}\text { Difficulty in defining the output } \\
\text { Difficulty in distinguishing output/input } \\
\text { Problem defining innovation and change }\end{array}$ \\
\hline Interactivity & $\begin{array}{l}\text { Difficulty in defining the output } \\
\text { Difficulty assigning the labor input } \\
\text { Influence of the customer }\end{array}$ \\
\hline Time factor & $\begin{array}{l}\text { Need to distinguish output/outcome } \\
\text { Different performance indicators }\end{array}$ \\
\hline Social nature & $\begin{array}{l}\text { Plurality of outputs } \\
\text { Plurality of performance }\end{array}$ \\
\hline Characteristics specific to public services & Difficulty in determining the volume of products \\
\hline No price & $\begin{array}{l}\text { Difficulty in weighting the outputs to determine the } \\
\text { aggregated outputs } \\
\text { Quality problems }\end{array}$ \\
\hline Collective consumption & $\begin{array}{l}\text { Problem determining the units of output } \\
\text { Quality problems }\end{array}$ \\
\hline Direct/indirect consumers & Different perceptions of the product and performance \\
\hline Principles of public services & Plurality of performances \\
\hline
\end{tabular}

\subsection{The Specific Characteristics of Public Services and their Consequences}

Public services have their own specific characteristics related to their public or non-market aspects that have an impact on how productivity is defined and measured. These characteristics that come on top of the previous ones are as follows: 1) the absence of price, 2) collective consumption, 3) the existence of direct and indirect consumers, 4) the adherence to principles of public service.

\section{a) The absence of price}

A key feature of public services is that they are provided free or at relatively low prices, which do not cover production costs. However, prices are necessary for measuring output volumes. For multi-output organizations, prices are also necessary to weight the different outputs to determine the aggregate output. Finally, they are an essential variable to identify 
changes in the quality of the output, when measuring productivity. In short, in the case of public services, the absence of price is an obstacle to measuring volumes, determining aggregate outputs and identifying changes in quality.

\section{b) Collective consumption of the output}

Certain public services are consumed collectively. These are pure public goods, that is to say non-rival and non-excludable. Their consumption by one individual does not deprive anyone else (there is no limit to the number of people who can simultaneously consume the good in question) and no one can be excluded from consuming it. This is the case, for example, of national defense, the justice system, fire departments and so on. It is particularly problematic in this case to measure productivity given the difficulty in determining the "units of output". Services consumed collectively may, in some cases, pose quality problems. For example, if the number of students in a class increases, the quality of education will eventually decrease. For services consumed collectively, measuring outcome is often more appropriate than measuring output.

\section{c) Direct and indirect consumers}

Unlike material goods or market services, public goods have two types of consumers (Greiner, 1996): direct consumers and indirect consumers, who have different perceptions of the output and performance, even if ultimately, they are the same group of individuals. Direct consumers are the ones who benefit directly from the service (the users). They tend to focus on the nature and quality of the service. Indirect consumers, namely the general public, the taxpayers, the citizens, are more concerned with economic and financial issues (as taxpayers) and the long-term socio-economic effects (as citizens). Thus, when an individual is sick and seeks treatment, he is a direct consumer of the hospital service, and is more concerned with getting well than the cost of the treatment procedures. When an individual is healthy, he is still an indirect consumer, and as a taxpayer is concerned with the cost of the hospital system, and as a citizen is concerned with long-term public health.

\section{d) The principles of public service}

The main principles of public service are continuity of service (in space and time), fairness and equal treatment. These principles are often viewed as barriers to productivity, since they introduce strict rules as to resource management and investment. For example, one cannot dismiss a public servant. Hiring and investments must obey strict rules that are codified and centralized, while productivity and innovation most often require quick and local responses.

But, despite these negative factors, the principles of public service can be the determinants of specific types of outputs and specific forms of performance. Public services do indeed produce outputs that can be called social or civic, insofar as they promote social relations based on equal treatment, fairness and justice. These "outputs" contribute to social cohesion, solidarity and collective and civic identity. In the case of the French Postal System, examples include the following direct or indirect outputs (Gadrey, Ghillebaert \& Gallouj, 1997): fair treatment of users (at the counters, along delivery routes), fair access, non-discrimination (of young people, foreigners) in customer contacts, assistance to marginalized populations, social tariffs, the contribution to regional planning and local development (rural areas, urban neighborhoods). These products are often not measured, or rather are often (in particular, and increasingly, in public service enterprises) considered as costs or extra costs (which must be reduced). The alternative approaches to productivity that we will discuss in the following section are intended to make invisible products and performance visible. 


\section{Methods for Measuring Productivity in Services}

There are different methods for measuring productivity in services, some of which are quite sophisticated, and others less so. In the first two paragraphs, we focus on how traditional methods (index-based, Data envelopment and econometric methods) are applied to services. In the third paragraph we discuss more critical alternative methods, which even question the relevance of the concept of productivity in some cases.

\subsection{Index-Based Methods}

Index-based methods are the simplest and most common. Djellal \& Gallouj (2008) present in detail all the classic problems associated with the use of these methods in manufacturing industry. These index-based methods are extended to services, which adds to the usual difficulties, the difficulties related to the specific characteristics of market and non-market (especially public) services.

Much of the problem lies in defining the numerator of the productivity ratio. In many services, determining the "unit of output" and measuring the output in volume terms (or at constant price) is not easy. Difficulties in defining the output (due to the intangibility and interactivity of services) make it particularly hard to break down changes in the value of an output into changes in volume and changes in price. Indeed, in services, volume is an abstract category that is not easy to define. It is therefore hard to assign it a unit price.

We can illustrate this problem through two classic examples: retailing and banking. "Retail service" cannot be reduced to volumes of goods sold. Yet the "production of retail services" is still valued using this indicator. Other essential features, such as product quality, the range of products offered, quality of service, geographic accessibility and so on, must be taken into account in attempting to calculate an accurate volume of retail service. Failure to do so will distort the productivity measurement. Retail outlets that provide enhanced service may mistakenly show lower productivity, while in reality the outputs being compared are different. Gadrey (1996) has conducted international comparisons that highlight these errors in defining volumes of output. For example, in the 1990s, large-scale food retailing in France seemed far superior to that of the U.S. in terms of productivity. In reality, different outputs were being compared, since in the U.S. retailing was characterized by its strong "service intensity" while in France, retailing had lagged behind and was still using a Fordist strategy based on standardization and economies of scale. Similarly, in the case of banking, the main indicator used to value production is "net banking income." However, this indicator does not reflect a volume of output, but a value that is extremely sensitive to the financial and monetary context. When used to compare the productivity of two banks, it can be misleading. Indeed, a bank can be particularly effective in terms of technical procedures (number of transactions, checks and files processed), but generate low net banking income, for example if it is located in an economically depressed area.

Statisticians have shown great imagination in attempting to resolve these problems of breaking down value into volume and price. Regarding the deflator (which allow to express value data as volume data), they have tried different solutions, including general prices index, consumption indices, wage indices, sale price index of a related service, price index for an industrial good related to the service in question, and so on. 
These deflation methods are questionable for numerous reasons (Gadrey, 1996). Using the prices index of the economy as a deflator cannot take account, in a given industry, of the productivity gains accompanied by a fall in the unit price of the outputs produced by the industry in question (and it may even reverse the sign). Deflation by the wage index of the branch is problematic when most of the value added consists of wages (as is the case in consultancy for example), because this will give the numerator and denominator of the productivity ratio approximately the same value, by definition leading to a productivity ratio close to 1 . Deflation by the prices index of an industrial activity similar to the service activity in question is based on a weak hypothesis. For example, deflating the output of architectural consultants by the construction costs index involves the questionable assumption that the unit price of a service of this type is proportional to the cost of construction. Similar doubts can be cast if a service's value (a banking and financial service, for example) is deflated by the prices index for related but more easily identifiable services (renting of safe deposit boxes, portfolio management, securities investments). These doubts are all the more serious since these related services are not representative of the service in question.

It is in the field of public services that the definition of volumes is the most problematic and the solutions proposed are the most questionable. This is the case, for example, of the solution that consists of defining the output of public administration by the sum of its costs, in other words measuring the output by the input. Clearly, valuing output in this way, which is justified by the absence of market prices, is not satisfactory. It makes the numerator and denominator of the productivity ratio identical. It is not surprising that it shows no change in productivity, since that is its implicit assumption.

A new solution (advocated by the OECD and Eurostat) has been being tested in recent years (OECD, 1999, Handler et al., 2005; Ashaye, 2001; Baxter, 2000; Pritchard, 2003). It consists in measuring the output by activities by developing catalogues of activities weighted by cost (Cost-Weighted Activity Index). For each public service considered, a list of key activities is established (intermediate steps or components of the final output), then a volume level is determined for each one (for example, the number of incidents or cases for a given period). In the absence of prices, the volumes of activity are usually aggregated using the relative costs of production of each type of activity, for a base year. This method, which attempts to identify the outputs of public services, is far preferable to input-based methods. However, it also has limitations. Indeed, indicators of the activity of public services are not strictly speaking indicators of their output. Counting up activities can result in misinterpretations. If, for example, a hospital introduces a technique that reduces the number of days' stay, the activity indicator (number of days' stay) will show a decline in productivity, which does not reflect reality. Similarly, when crime decreases, the productivity of the police also decreases, if it is defined by the number of arrests.

\subsection{DEA Methods and Econometric Methods}

Our purpose is obviously not to provide an exhaustive review of an extensive and technical literature. We will confine ourselves here to briefly discussing in general terms the diverse objectives pursued in the literature in question.

Data Envelopment Analysis (DEA) is by far the most widely used non-parametric method. It involves building a production frontier that corresponds to best practices in terms of technical efficiency. The efficiency of other organizations is measured by comparison to the empirically established frontier benchmark. Numerous attempts have been made to apply the DEA method to services. They differ, first, by the criteria used to compare units of output 
examined. Some studies compare the public and private sector, others compare entities within the same organization, and still others compare by geographical location (local, regional, national, international). Some studies are purely methodological and do not include any measurements. Others compare the results from the DEA method to those produced by other methods.

Likewise, many studies have also sought to extend econometric methods developed elsewhere to services. Once again, it is clear that these methods can be applied to any service sector (insurance, banking, retail, etc., see Djellal \& Gallouj, 2008). The econometric approach to productivity has a number of advantages (OECD, 2001). In particular, econometrics is able to take into account adjustment costs and variations in resource use. This is valuable, since the cost of these variations depends on how fast the resources are deployed. Moreover, the econometric approach can adapt to any hypothesis concerning the form of technical change, whereas index-based methods rely on the assumption that technical progress is neutral, as described by Hicks (in which factors of production are saved in the same proportions). But the econometric approach also has a number of disadvantages (OECD, 2001). First, the refinement of solutions to complex technical problems calls into question the validity of certain results. Moreover, for statistical institutes, these econometric methods require considerable resources in terms of data, equation system updates and training for users of statistics.

\subsection{Multi-Criteria Approaches}

The specific characteristics of services and the rise, beyond the tertiary sector, of informational, cognitive and service-related dimensions challenge the absolutism of the concept of productivity. When there is controversy about exactly what constitutes the output or performance of a given activity at a given point in time, and no single definition or indicator is technically superior, it is necessary to give up the notion of measurement in favor of evaluation. In the multi-criteria approaches in terms of "worlds of production" that we are now considering, the recommendation is to abandon the absolute power of a single ratio (productivity, or growth), and replace it with a pluralist and flexible evaluation system in which productivity is merely one concept among many. The multi-criteria approaches used to evaluate the performance of services will therefore fall within the integration perspective that we discussed earlier.

Drawing freely from the work of Boltanski and Thévenot (1991), we suggest several worlds of production which correspond to different value and justifications systems:

- The industrial and technical world in which output is defined in terms of volumes, flows and technical operations;

- The market and financial world, which considers the "output" in terms of value and monetary and financial transactions;

- The relational or domestic world that values interpersonal relationships, empathy and trust relationships consolidated over time, and regards the quality of relationships as a key factor in evaluating output;

- The civic world (where social relations are based on a concern for equal treatment, fairness and justice);

- The world of innovation (the world of creativity or inspiration);

- The world of reputation (the world of brand image). 
Each of these worlds may be associated with output types and performance types, which can be considered in terms of different time horizons (short-term, long-term).

These different conceptions of output or performance may oppose or reinforce each other. For example, a good civic performance (high level of social quasi-benefits or civic outputs) can degrade technical performance (productivity) or market performance (competitiveness). This is what has led some public service providers to seek to restrict this type of civic outputs in a logic of privatization of public services and new public management. Similarly, an improvement in technical performance can lead to a deterioration in market performance. The phenomenon can occur, for example, when bank cards are issued as a matter of course (volume effect) without respecting certain "security" conditions. But conversely, these different types of performance can complement and reinforce one another. For example, an improvement in relational performance (reflected, for example, by increasing the level of customer loyalty) generally has a positive impact on market performance. Similarly, improved technical performance can induce growth of market performance: an increase in the number of accounts opened per bank employee will likely be accompanied by an increase in net banking income per employee.

Tables 2 and 3 illustrate this multi-criteria grid in the case of a market service (insurance) and a non-market service (a business incubator).

In the case of insurance, technical productivity is only one dimension of performance and civic performance is possible. Civic performance is not, as one might think, the exclusive preserve of public services. Indeed, a private insurance company may also pursue performance objectives in this area, when, for example, it imposes limits in searching for private background information on its customers or adopting a premium structure that evens out differences between generations or social classes.

Furthermore, civic or relational performance can also be quantified. For example, (internal or external) improved customer satisfaction indicators and reduced user turnover are relational performance indicators. Changes in production and the share of social quasi-benefits may, to some extent, be indicators of civic performance. The same is true for innovation performance. Although Table 2 does not reflect the outputs and performance of this world, it is conceivable that the rate of (incremental) innovation and the percentage of solutions to problems encountered during the test phase of an innovative project or the percentage of solutions codified (routinized) and transferred to a generalized application are indicators of innovation performance. 
Table 2: An application of the multi-criteria framework to insurance (Gadrey, 1996)

\begin{tabular}{|c|c|c|c|c|}
\hline & $\begin{array}{l}\text { Industrial and } \\
\text { technical world }\end{array}$ & $\begin{array}{c}\text { Market and financial } \\
\text { world }\end{array}$ & $\begin{array}{l}\text { Relational or } \\
\text { domestic world }\end{array}$ & Civic world \\
\hline $\begin{array}{l}\text { Direct output } \\
\text { (short term) }\end{array}$ & $\begin{array}{l}\text { 'Volume' of claims, } \\
\text { 'volumes' of contracts } \\
\text { (by homogeneous } \\
\text { groups of cases) }\end{array}$ & $\begin{array}{l}\text { Premiums, } \\
\text { compensation claims } \\
\text { paid out }\end{array}$ & $\begin{array}{l}\text { Quality of direct } \\
\text { relations between } \\
\text { staff and customers } \\
\text { (business relations, } \\
\text { relations with } \\
\text { experts, etc.) }\end{array}$ & $\begin{array}{l}\text { Refusal to go too far } \\
\text { in the search for } \\
\text { private information on } \\
\text { the insured (health, } \\
\text { history, etc.) }\end{array}$ \\
\hline $\begin{array}{l}\text { Performance } \\
\text { relative to } \\
\text { direct output }\end{array}$ & $\begin{array}{l}\text { Technical } \\
\text { productivity, ability to } \\
\text { process technical } \\
\text { operations more } \\
\text { quickly, to settle } \\
\text { claims more } \\
\text { efficiently, reductions } \\
\text { in waiting periods and } \\
\text { error rates, etc. }\end{array}$ & $\begin{array}{l}\text { Increase in premium } \\
\text { levels, improvement } \\
\text { in the } \\
\text { claims/premiums } \\
\text { ratio, yield on short- } \\
\text { term investments, } \\
\text { etc. }\end{array}$ & $\begin{array}{l}\text { Improvement in } \\
\text { customer satisfaction } \\
\text { indicators in respect } \\
\text { of the service } \\
\text { relationship }\end{array}$ & $\begin{array}{l}\text { Proportion of contracts } \\
\text { in which the company } \\
\text { agrees to accept } \\
\text { additional risks for } \\
\text { civic reasons or to } \\
\text { avoid discrimination }\end{array}$ \\
\hline $\begin{array}{l}\text { Indirect output } \\
\text { (long term) }\end{array}$ & \multirow{2}{*}{$\begin{array}{l}\text { Concepts of little } \\
\text { relevance except } \\
\text { perhaps for evaluating } \\
\text { the impact of } \\
\text { insurance on the } \\
\text { technical performance } \\
\text { of insured companies } \\
\text { and hence on } \\
\text { economic growth and } \\
\text { innovation. }\end{array}$} & $\begin{array}{l}\text { Financial stability } \\
\text { and security (of } \\
\text { customers and of the } \\
\text { company) }\end{array}$ & $\begin{array}{l}\text { Customer } \\
\text { loyalty/retention }\end{array}$ & $\begin{array}{l}\text { Premium structures } \\
\text { that equalise, for } \\
\text { example, differences } \\
\text { between the } \\
\text { generations or social } \\
\text { classes (Michel } \\
\text { Albert's 'Rhenish' } \\
\text { model) }\end{array}$ \\
\hline $\begin{array}{l}\text { Performance } \\
\text { relative to } \\
\text { indirect output }\end{array}$ & & $\begin{array}{l}\text { Company's long- } \\
\text { term financial yield } \\
\text { indicators. } \\
\text { Contribution of } \\
\text { insurance to the } \\
\text { financial health of } \\
\text { customers and of the } \\
\text { economy. }\end{array}$ & $\begin{array}{l}\text { Reduction in } \\
\text { customer turnover }\end{array}$ & $\begin{array}{l}\text { Support for a form of } \\
\text { financial solidarity } \\
\text { through inter-class or } \\
\text { inter-generational } \\
\text { pooling of risks }\end{array}$ \\
\hline
\end{tabular}

The second application of our multi-criteria grid is devoted to business incubators. These are local and most often non-market services which are incentive and support mechanisms for business start-ups. Table 3 illustrates the multiple 'outputs' and performance of business incubators by combining two variables: 1) the symbolic space, that is to say the different worlds of production, and 2) space-time analysis in which the short term (time required to provide direct output) corresponds to the company's time in the incubator and the long term (indirect output) starts when the company leaves the incubator.

In the industrial and technical world, the incubator provides direct outputs such as hosting, consulting and training, whose long term goal (the indirect output) is business start-ups and job creation. In the market and financial world, the main (direct) outputs are access to lower cost (shared cost) services and to financing, while the indirect (long term) outputs are, for example, financial revenues: sales and profit for companies, wages for employees and local tax revenue for local governments.

Regarding the relational or domestic world, an incubator can be seen as a place intended to promote formal and informal relationships (trust relationships, empathy, inclusion in internal 
and external networks). This type of relationship helps (in the long term) to develop loyalty to the local area. Incubators also help to produce short term civic outputs, by providing support to specific populations or geographical areas (socio-economically disadvantaged), as well as long-term civic outputs, such as social cohesion and regional development. The addition of new services and support for innovative projects by incubators are examples of direct outputs in the world of innovation. Examples of this world's indirect outputs include the creation of a culture of entrepreneurship and innovation, and consolidation of local innovation systems. And finally, in the world of reputation, incubators produce an essential output for local governments (municipalities, counties, regions), namely brand image. This short term or long term output is a key factor for the attractiveness of regions.

\section{Table 3: A multi-criteria framework for analyzing the output and performance of business incubators}

\begin{tabular}{|c|c|c|c|c|c|c|}
\hline & $\begin{array}{l}\text { Industrial and } \\
\text { technical world }\end{array}$ & $\begin{array}{c}\text { Market and } \\
\text { financial world }\end{array}$ & $\begin{array}{c}\text { Relational or } \\
\text { domestic world }\end{array}$ & Civic world & $\begin{array}{c}\text { Innovation } \\
\text { world }\end{array}$ & $\begin{array}{c}\text { Reputational } \\
\text { world }\end{array}$ \\
\hline $\begin{array}{l}\text { Direct } \\
\text { output } \\
\text { (short- } \\
\text { term) } \\
\text { during a } \\
\text { company } \\
\text { 's time } \\
\text { in the } \\
\text { incubato } \\
r\end{array}$ & $\begin{array}{l}\text { - Accommodation } \\
\text { (office provision) } \\
\text { - Basic services } \\
\text { - Advice, } \\
\text { assistance, } \\
\text { training } \\
\text { - Market } \\
\text { visibility? }\end{array}$ & $\begin{array}{l}\text { - Services at reduced } \\
\text { cost } \\
\text { - Access to finance } \\
\text { - Turnover managed } \\
\text { during time in } \\
\text { incubator }\end{array}$ & $\begin{array}{l}\text { - Individualised } \\
\text { answers } \\
\text { - Interpersonal } \\
\text { arrangements } \\
\text { - Trust } \\
\text { - Personalised } \\
\text { advice } \\
\text { - Breaking down of } \\
\text { isolation } \\
\text { - Integration into } \\
\text { internal network } \\
\text { - Integration into } \\
\text { external networks } \\
\text { (consultants) } \\
\text { - One-stop shop }\end{array}$ & $\begin{array}{l}\text { - Support for } \\
\text { particular } \\
\text { populations or } \\
\text { industries }\end{array}$ & $\begin{array}{l}\text { - Addition of } \\
\text { new (innovative) } \\
\text { services } \\
\text { - Support for } \\
\text { innovative } \\
\text { projects }\end{array}$ & $\begin{array}{l}\text { - Short-term image } \\
\text { of the locality, } \\
\text { department or } \\
\text { region }\end{array}$ \\
\hline $\begin{array}{l}\text { Perform } \\
\text { ance } \\
\text { relative } \\
\text { to the } \\
\text { direct } \\
\text { output }\end{array}$ & $\begin{array}{l}\text { - Productivity } \\
\text { gains } \\
\text { - Economies of } \\
\text { scale } \\
\text { - Improvement in } \\
\text { industrial quality } \\
\text { - Incubator } \\
\text { occupancy rate } \\
\text { - Failure rate } \\
\end{array}$ & $\begin{array}{l}\text { - Improvement in } \\
\text { 'financial health' } \\
\text { indicators } \\
\text { - Competitiveness } \\
\text { relative to rival } \\
\text { organisations (cost } \\
\text { of creating one job } \\
\text { compared with other } \\
\text { organisations) }\end{array}$ & $\begin{array}{l}\text { - Improvement in } \\
\text { organisation's } \\
\text { relational qualities } \\
\text { (service } \\
\text { relationships, } \\
\text { integration into } \\
\text { networks) }\end{array}$ & $\begin{array}{l}\text { Improvement of } \\
\text { civic qualities }\end{array}$ & $\begin{array}{l}\text { Improvement of } \\
\text { innovation } \\
\text { quality }\end{array}$ & $\begin{array}{l}\text { Improvement of } \\
\text { reputation and } \\
\text { image }\end{array}$ \\
\hline $\begin{array}{l}\text { Indirect } \\
\text { output } \\
\text { (long } \\
\text { term) on } \\
\text { exit from } \\
\text { incubato } \\
\mathrm{r}\end{array}$ & \begin{tabular}{|l|} 
- Company \\
formation \\
- Creation of \\
direct and indirect \\
jobs
\end{tabular} & $\begin{array}{l}\text { - Generation of } \\
\text { turnover (direct and } \\
\text { indirect) } \\
\text { - Generation of } \\
\text { wages (direct and } \\
\text { indirect) } \\
\text { - Generation of local } \\
\text { taxes }\end{array}$ & $\begin{array}{l}\text { - Establishment of } \\
\text { loyalty to local area }\end{array}$ & $\begin{array}{l}\text { - Regeneration } \\
\text { of disadvantaged } \\
\text { areas } \\
\text { - Redeployment }\end{array}$ & $\begin{array}{l}\text { Creation of a } \\
\text { local innovation } \\
\text { system } \\
\text { Creation of an } \\
\text { entrepreneurial } \\
\text { culture }\end{array}$ & $\begin{array}{l}\text { - Long-term image } \\
\text { of the locality, } \\
\text { department or } \\
\text { region }\end{array}$ \\
\hline $\begin{array}{l}\text { Perform } \\
\text { ance } \\
\text { relative } \\
\text { to the } \\
\text { indirect } \\
\text { output }\end{array}$ & $\begin{array}{l}\text { - Improvement of } \\
\text { contribution to } \\
\text { (local, national) } \\
\text { economic growth } \\
\text { - Evolution of } \\
\text { number of } \\
\text { business start-ups } \\
\text { - Evolution of the } \\
\text { number of jobs } \\
\text { created } \\
\text { - Evolution of the } \\
\text { quality of these } \\
\text { jobs } \\
\text { - Rate of surviving } \\
\text { companies after } x \\
\text { years }\end{array}$ & $\begin{array}{l}\text { - Improvement in the } \\
\text { generation of the } \\
\text { various types of } \\
\text { revenue }\end{array}$ & $\begin{array}{l}\text { - Consolidation of a } \\
\text { local system or } \\
\text { network of services } \\
\text { (long-term } \\
\text { integration into this } \\
\text { system) }\end{array}$ & $\begin{array}{l}\text { - Long-term } \\
\text { improvement of } \\
\text { civic qualities }\end{array}$ & $\begin{array}{l}\text { Consolidation of } \\
\text { local innovation } \\
\text { system and long- } \\
\text { term integration } \\
\text { into that system }\end{array}$ & $\begin{array}{l}\text { Long-term } \\
\text { improvement of } \\
\text { reputation and } \\
\text { image }\end{array}$ \\
\hline
\end{tabular}




\section{Productivity Strategies of Service Firms}

As we have seen, the specific characteristics of services have an impact on the definition and measurement of productivity. But they also impact the strategies implemented to increase productivity. Productivity strategies can be analyzed using the assimilation, demarcation, integration framework mentioned earlier that was developed for analyzing innovation (Gallouj, 1994).

Three groups of generic productivity strategies are identified, (assimilation strategies, demarcation strategies and integration strategies) which differ in the productivity levers used, the way the levers are incorporated into the strategy and the place occupied by productivity in the strict sense in the strategy in question.

\subsection{Assimilation Strategies: Productivity as a Target}

Assimilation strategies aim to make services "goods like any other," in other words, to eliminate the specific characteristics of services outlined in Section 2. The idea is to make services more tangible, less interactive, less subjective (that is to say less socially embedded), so they differ as little as possible from goods. This "assimilation" of services, which is synonymous with industrialization, may rely on various well-known mechanisms: standardization, mechanization of production processes, mechanization of the service itself (replacing services with tangible goods). Assimilation or industrialization often equates to applying to services the Fordist production model dominant in heavy industry in the post-war era (especially the automotive industry). The textbook example of this type of strategy is the fast food industry (and especially McDonald's). Assimilation or industrialization, it should be noted, has sometimes been introduced as a strategic rule in the literature. Levitt (1972) advocates systematic industrialization of services by using industrial methods of production. Shostack (1984) likewise sees this industrialization strategy as a solution to the "divergence" (degree of freedom) and the complexity of the service delivery. Like other authors (Lovelock, 1992; Kingman-Brundage, 1992), she recommends developing delivery models ("flowcharting," "blueprinting"), which are veritable "manuals" of service delivery.

When assimilation is successful, the productivity factors are identical to those of industry. Productivity can then be improved by using any of the traditional factors of productivity (technical, human, organizational). Assimilation strategies contributed to the success of the Fordist growth model. They have not disappeared in the post-Fordist model, and in fact are widely used, for example, in fast food, low cost airlines and discount retailers. But they are no longer dominant. Similarly, in the assimilationist strategy, traditional indicators of productivity (that is to say, quantitative measurements by groups of standard cases) are operative. Measuring these indicators can certainly pose problems in services, but it is possible to resolve them by methodological efforts and technical refinements.

\subsection{Demarcation Strategies: Outcome and Effectiveness Regime}

Given the specific characteristics of services, the industrialization advocated by assimilation strategies is not always easy to implement, nor, for that matter, is it desirable. So it is important not to eliminate the specificities of services, which meet a social demand. 
This determination to maintain the specificities of services is not inconsistent with productivity or performance objectives (Walther et al., 2011; Viitamo \& Toivonen, 2013). Service firms do indeed implement specific strategies of rationalization of processes and products that target performance, which are not to be confused with industrialization.

When speaking of knowledge-intensive and relationship-intensive services (professional services), Gadrey (1994) uses the term "professional" or "cognitive" rationalization (as opposed to industrial rationalization or industrialization). This consists of three interrelated strategies: 1) typification of cases (that is to say, identification of standard cases, standard contracts, standard solutions), 2) formalization of problem solving procedures (development of methods), 3) use of individual or organizational routines (automatic response programs to problems encountered).

Cognitive rationalization, first, is a means of saving resources, in particular time. It is a source of productivity gains. Nevertheless, the dominant criterion for judging performance is not productivity. Professional rationalization favors multi-criteria and multi-actor indicators, with an emphasis on monitoring performance and compliance with the profession's quality standards. It also promotes the capitalization of past experiences and the establishment of an organizational memory. And finally, by exploiting the differential in expertise and the competitive edge in terms of methodology, cognitive rationalization enables firms to establish a power relationship vis-à-vis their customers.

In short, we can say that demarcation strategies are not productivity strategies per se. They do not contribute to a "productivity regime," but rather an "effectiveness regime" focused primarily on the outcome (in which productivity does not necessarily disappear, but occupies a relatively small place).

\subsection{Integration Strategies: Multi-Criteria Evaluation}

Services firms operating in the same sector may, for various reasons, make different strategic choices in terms of productivity and performance by implementing demarcation or assimilation strategies. This is the case for example of McDonald's, which uses an assimilation strategy (industrialization) as opposed to a gourmet restaurant, which uses a demarcation strategy. Similarly, in the hotel sector, budget hotel chains with the same standardized (prefabricated) architectural components can be distinguished from luxury boutique hotels that favor a demarcation strategy.

But these two opposing strategies of demarcation and assimilation may also be used simultaneously in the same company. This type of integration strategy is particularly common in large companies in banking, insurance, retailing, tourism and transport, for example. This is the case for example of multi-channel banking, which combines face-to-face service in branches, self-service banking (ATM) and home banking.

These strategies, which at times have been described as synthesis or integration strategies, are in reality frequently part of a two-phase historical process: one phase dominated by assimilation strategies (industrialization) and a second phase emphasizing differentiation strategies (increasing prominence of the service dimension). The term synthesis or integration strategy is used because the demarcation strategies introduced do not replace the assimilation strategies. 
These integration strategies argue for a multi-criteria evaluation of performance, in which productivity does not disappear, but becomes less important. Overall, in the post-Fordist economy (emphasizing services, innovation, quality and knowledge), the performance strategies implemented in firms and sectors are characterized by their diversity. They contribute to (or are part of) a "performance regime" which does not reject the productivity regime, but considers it as just one category among others.

\section{Conclusion}

In this article, we put the notion of productivity to the test of services. The main conclusion to be drawn is that we should be wary of cognitive lock-ins that perpetuate (inappropriate or even obsolete) practices or ideas, not out of necessity but merely out of habit.

The notion of productivity comes up against certain analytical difficulties when applied to services. In some cases, particularly when relatively homogeneous and weakly interactive units of output can be identified, these difficulties can be resolved technically, and the concept remains relevant. Thus, when a firm's efforts are focused on developing standardized products, its strategy can be said to come to the rescue of the concept. In other cases, it is debatable whether the concept should be retained, either because an indicator is wrongly considered to reflect productivity, when in fact it does not, given the technical solutions adopted, or because extraordinary measures are being taken keep a non-valid indicator alive.

In the area of public services it is important to be extremely cautious, since the general difficulties of services are compounded by the difficulties associated with the specific characteristics of public services, namely the absence of price, the collective consumption, the distinction between direct and indirect consumers, compliance with the principles of public service.

In all cases (market and public services), especially when measuring productivity for strategic purposes, a cautious approach makes multi-criteria evaluations of performance mandatory. Such an approach takes account of the multiple dimensions of performance which can oppose or reinforce each other: technical performance of course, but also commercial performance (relative to monetary and financial values), civic performance (relative to equity, equal treatment, social cohesion, respect for the environment, etc.) and relational performance (quality of interpersonal relations, empathy, trust relations, etc.).

We discussed in this paper three different types of productivity or performance strategies. Assimilation (or industrialization) strategies involve transforming services into quasi-goods, i.e. reducing their intangibility and interactivity thanks to mechanisation, division of labour and specialisation to services, for example. Differentiation strategies for their part seek to maintain service specificities by implementing relevant rationalisation techniques and methods (or professional rationalization). Integration strategies, finally, involve combining the previous two opposing strategies in different ways. Integrative strategies fit particularly well with the multicriteria evaluation of performance.

We acknowledge that our discussion in this article goes beyond the service sector. It also relates to agricultural or industrial sectors. This is explained by the convergence between goods and services and in particular by the increased prominence of service, the service relationship and "servitization" (Vandermerwe \& Rada, 1998) as a mode of coordination between economic agents in the sectors that manufacture industrial and agricultural goods. 


\section{Bibliography}

Ashaye, T. (2001). Recent developments in the measurement of general government output. Economic Trends, 76, November, 41-44.

Barros, C.P. \& Matias, A. (2006). Assessing the efficiency of travel agencies with a stochastic cost frontier: a Portuguese case study. International journal of tourism research, 8(5), 367379.

Baumol, W. (1967). Macroeconomics of unbalanced growth: the anatomy of urban crisis. The American Economic Review, $n^{\circ} 3$, June, 415-426.

Baxter, M. (2000). Developments in the measurement of general government output. Economic Trends, $n^{\circ} 562$, September, 3-5.

Boltanski, L., \& Thévenot, L. (1991). De la justification. Les économies de la grandeur. Paris: Gallimard.

Bonneville, L. (2001). Un regard sociologique sur la notion de productivité dans le passage à la nouvelle économie. Hermès: revue critique, $n^{\circ}$ 8, 1-16.

Clark, C., (1940). The conditions of Progress and Security. London: Mac Millan.

Coombs, R., \& Miles, I. (2000). Innovation measurement and services: the new problematique. In Metcalfe, S., \& Miles, I. (Eds), Innovation systems in the service economy. Measurement and case study analysis (pp. 85-103). Boston: Kluwer.

Delaunay, J.-C. \& Gadrey, J. (1987). Les enjeux de la société de services. Paris: Presses de la Fondation des Sciences Politiques.

Den Hartigh, E. \& Zegveld, M. (2011). Service productivity: how to measure and improve it? In Demirkan, H., Spohrer, J. C. \& Krishna, V. (eds.), Service systems implementation, service science: research and innovations in the service economy (pp. 183-198). Berlin: Springer.

Djellal, F., \& Gallouj, F. (2008). Measuring and improving productivity in services: issues, strategies and challenges. Cheltenham: Edward Elgar.

Dopuch, N., Gupta, M., Simunic, D.A \& Stein, M.T. (2003). Production efficiency and the pricing of audit services. Contemporary Accounting Research, 20 (1), 47-77.

Fourastié, J. (1949). Le Grand Espoir du XX $X^{e}$ siècle. Paris: PUF.

Gadrey, J. (1996). Services: la productivité en question. Paris: Desclée de Brouwer.

Gadrey, J. (2000). The characterization of goods and services: an alternative approach. Review of Income and Wealth, 46, $n^{\circ} 3$, September, 369-387.

Gadrey, J., (1994). Les relations de services dans le secteur marchand. In De Bandt, J. \& Gadrey, J. (Eds). Relations de service, marchés des services (pp. 23-42). Paris: CNRS Edition.

Gadrey, J., (2002). Croissance et productivité: des indicateurs en crise larvée. Travail et Emploi, $n^{\circ}$ 91, July, 9-17.

Gadrey, J., Ghillebaert, E., \& Gallouj, F. (1997). Analyser les prestations de cohésion sociale "hors cadre" des services publics et leur coût: le cas des relations de guichets à La Poste. Politiques et Management Public, Vol. 15, n4, December, 119-144.

Gallouj, F. (1994). Economie de l'innovation dans les service. Paris: Editions L'Harmattan, Logiques économiques.

Gallouj, F., \& Weinstein, O. (1997). Innovation in services. Research Policy, 26 (4-5), 537556.

Ganz, W. \& Mörschel, I. (2011). More productive through cross-linking: the strategic partnership «Productivity of services». $21^{\text {st }}$ RESER International conference, «Productivity of Services NextGen: Beyond Output/Input », Hamburg, 8-10 September. 
Greiner, J.M. (1996). Positioning performance measurement for the twenty-first century. In Halachmi, A., \& Bouckaert, G. (Eds). Organizational performance and measurement in the public sector (pp. 11-50). London: Quorum Books.

Griliches, Z. (Ed) (1984). Output measurement in the service sectors. Chicago: The University of Chicago Press.

Handler, H., Koebel, B., Reiss, P., \& Schratzenstaller, M. (2005). The size and performance of public sector activities in Europe, WIFO (Osterreichisches Institut Für Wirstschaftsforschung), Working Papers $\mathrm{n}^{\circ} 246$.

Hempell, T. (2005). What's spurious, what's real? Measuring productivity impacts of ICT at the firm level. Empirical Economics, 30, 427-464.

Hill, P. (1977). On goods and services. Review of Income and Wealth, $n^{\circ} 1,315-338$.

Keh, H.T. \& Chu, S. (2003). Retail productivity and scale economies at the firm level: a DEA approach. The International Journal of Management Science, 31, 75-82.

Kicherer, F., Hottum, P., Janeschek,S., \& Bienzeisler, B. (2011). Service productivity in the context of the service life cycle. $21^{\text {st }}$ RESER International conference, "Productivity of Services NextGen: Beyond Output/Input », Hamburg, 8-10 September.

Kingman-Brundage, J. (1992). The ABCs of Service System Blueprinting. In Lovelock C. (Ed.), Managing services (pp. 96-102). Englewood Cliffs: Prentice-Hall International Editions.

Levitt, T. (1972). Production line approach to service. Harvard Business Review, 50, September-October, 41-52.

Linna, P., Pekkola, S., Ukko, J. \& Melkas, H. (2010). Defining and measuring productivity in the public sector: managerial perceptions. International Journal of Public Sector Management, 23(3), 300-320.

Lovelock, C. (1992). A Basic Toolkit for Service Managers. In Lovelock C. (Ed.), Managing services (pp. 17-30). Englewood Cliffs: Prentice-Hall International Editions.

Martin, C.R.J.; Horne, D.A. \& Chan, W.S. (2001). A perspective on client productivity in business-to-business consulting services. International Journal of Service Industry Management, 12(2), 137-149.

OECD (1999). Productivity measurement in the general government sector, Expert meeting, 18-19 mars, Paris, PUMA/HRM/M(99)1.

OECD (2001). Mesurer la productivité: Mesurer la croissance de la productivité par secteur et pour l'ensemble de l'économie, Paris, (www.sourceOECD.org).

Oï, W. (1992). Productivity in the Distributive Trades: The Shopper and the Economies of Massed Reserves. In Griliches, Z. (Ed). Output Measurement in the Service Sectors. (pp. 161-191). Chicago: University of Chicago Press.

Osberg, L. \& Sharpe, A. (1998). “An Index of Economic Well-being for Canada," Research Paper, Applied Research Branch, Human Resources Development, Canada.

Pritchard, A. (2003). Understanding government output and productivity. Economic Trends, $n^{\circ} 596$, July, 27-40.

Reynolds, D., \& Thompson, G.M (2007). Multiunit restaurant productivity assessment using three-phase data envelopment analysis. International journal of hospitality management, 26(1), 20-32.

Schwartz, Y. (Ed) (1992). L'évaluation économique à l'épreuve des services, Report for the Ministry of Research and Technology, Centre APST Université Aix-en-Provence.

Shostack, G.L., (1984). Service Design in the Operating Environment. In George, W., \& Marshall, C. (Eds.). Developing New Services (pp. 27-43). Chicago: American Marketing Association, Proceedings Series.

Smith, A., The wealth of nations (1960). New York: The Modern Library, 1960 (1 ${ }^{\text {st }}$ edition 1776). 
Stiglitz, J., Sen, A., \& Fitoussi, J.-P. (2009). Report of the commission on the measurement of economic performance et social progress, Paris, September.

Sturm, F., Rannacher, A., Straub-Bila, L., Stranzenbach, R. \& Mutze-Niewöhner, S. (2011). Productivity measurement of knowledge intensive services: towards adaptable service performance evaluation systems. $21^{\text {st }}$ RESER International conference, "Productivity of Services NextGen: Beyond Output/Input », Hamburg, 8-10 September.

Vandermerwe, S., Rada, J. (1988). Servitization of Business: Adding Value by Adding Services. European Management Journal 6(4), 314-324.

Viitamo, E. (2012). Productivity as a competitive edge of a service firm: theoretical analysis and a case study of the Finnish banking industry. $\mathrm{PhD}$ thesis, Aalto University.

Viitamo, E. \& Toivonen, M. (2013). Is the concept of service productivity compatible with the framework of service dominant logic? Economies et Sociétés, Séries EGS, $\mathrm{n}^{\circ} 14$ (forthcoming).

Walther S., Eymann, T. \& Horbel, C. (2011). A service-dominant logic based service productivity improvement framework. $21^{\text {st }}$ RESER International conference, "Productivity of Services NextGen: Beyond Output/Input », Hamburg, 8-10 September. 